\title{
Expression of vascular endothelial growth factor in response to high glucose in rat mesangial cells
}

\author{
N H Kim ${ }^{1}$, H H Jung ${ }^{2}$, D R Cha ${ }^{3}$ and D S Choi ${ }^{1}$ \\ ${ }^{1}$ Department of Endocrinology, Korea University College of Medicine, Seoul, South Korea \\ ${ }^{2}$ Department of Otolaryngology-Head and Neck Surgery, Korea University College of Medicine, Seoul, South Korea \\ ${ }^{3}$ Department of Nephrology, Korea University College of Medicine, Seoul, South Korea \\ (Requests for offprints should be addressed to D S Choi, Department of Endocrinology, Korea University College of Medicine, $126-1$ An Am Dong 5 Ka, \\ Seung Buk Ku, Seoul, 136-705, South Korea)
}

\begin{abstract}
Diabetic nephropathy associated with hyperglycemia is characterized by glomerular hyperfiltration and endothelial dysfunction. Vascular endothelial growth factor (VEGF) is known to be primarily involved in neoangiogenesis and increased endothelial permeability. The purpose of this study was to investigate VEGF expression in response to high glucose in rat cultured mesangial cells and to identify its signal pathway via protein kinase $\mathrm{C}(\mathrm{PKC})$. Rat mesangial cells were cultured with different concentrations of glucose: normal (5 mM D-glucose), medium (15 mM D-glucose) and high (30 mm D-glucose). Calphostin-C as a PKC inhibitor and phorbol myristate acetate (PMA) as a PKC downregulator were instillated into culture media to evaluate the role of PKC in mediating the glucose-
\end{abstract}

induced increase in VEGF expression. High glucose increased expression of VEGF at the mRNA and protein levels, identified by semi-quantitative RT-PCR and western blotting, within $3 \mathrm{~h}$ and in a time- and glucose concentration-dependent manner. Calphostin-C and PMA inhibited glucose-induced increases in VEGF expression at the mRNA and protein levels. In conclusion, high glucose can directly increase VEGF expression in rat mesangial cells via a PKC-dependent mechanism. These results suggest that VEGF could be a potential mediator of glomerular hyperfiltration and proteinuria in diabetic nephropathy.

Journal of Endocrinology (2000) 165, 617-624

\section{Introduction}

Numerous factors have been recognized as contributing to the pathogenesis and progression of diabetic nephropathy, including glycemic control (Pugh et al. 1993), intraglomerular and systemic hypertension (Pugh et al. 1993), role of the renin-angiotensin system (Wolf \& Ziyadeh 1997), several growth factors and cytokines (Sharma \& Ziyadeh 1997) and genetic predisposition (Pettitt et al. 1990). Even though the precise mechanism of diabetic nephropathy is unclear, hyperglycemia is one of the independent risk factors for the development of diabetic microvascular disease.

It has recently been proposed that vascular endothelial growth factor (VEGF) plays an important role in increased vascular permeability and neoangiogenesis (Connolly et al. 1989, Leung et al. 1989, Senger et al. 1990). The VEGF family comprises a 34-42 kDa heparin-binding, dimeric, disulfide-bound mitogen. Molecular cloning of cDNA for the VEGF family has revealed the existence of at least five isoforms in human tissues, formed by alternative splicing of mRNA to yield VEGF transcripts encoding polypeptides of 206, 189, 165, 145 and 121 (Ferrara et al. 1992).
Rat homologs have been demonstrated as VEGF188, VEGF164 and VEGF120 corresponding to human VEGF189, VEGF165 and VEGF121 respectively (Conn et al. 1990, Ladoux \& Frelin 1993). Even though the physiologic roles of these transcripts are unclear, VEGF165 is the most abundant isoform expressed in most of the normal human tissues and is readily detectable in human serum (Ferrara et al. 1992, Senger et al. 1993).

VEGF is known to be implicated in the pathogenesis of neovascularization and endothelial dysfunction in diabetic vascular complications, especially in diabetic retinopathy (Connolly et al. 1989, Leung et al. 1989, Williams et al. 1997). VEGF may have a key role in the regulation of glomerular permeability to protein, as in situ hybridization of VEGF reveals predominant expression in glomerular epithelial cells (Brown et al. 1992) and cultured human mesangial cells express VEGF transcripts; this is also enhanced by fetal calf serum and transforming growth factor- $\beta 1$ (Iijima et al. 1993). The potential for increased vascular permeability induced by VEGF makes it an attractive candidate as a mediator of glomerular hyperfiltration and increased permeability to macromolecules if mesangial cells produce more VEGF in response to high 
Table 1 Oligonucleotide sequences of PCR primers and expected lengths of their PCR products

\begin{tabular}{|c|c|c|c|}
\hline & Oligonucleotide sequences & $\begin{array}{l}\text { Expected } \\
\text { length }\end{array}$ & $\begin{array}{l}\text { PCR } \\
\text { products } \\
\text { (bp) }\end{array}$ \\
\hline \multicolumn{4}{|l|}{ Primer } \\
\hline rVEGF1 & & VEGF188 & 514 \\
\hline $\mathrm{S}$ & 5'GACCCTGGTGGACATCTTCCAGGA3' & VEGF164 & 462 \\
\hline AS & 5'GGTGAGAGGTCTAGTTCCCGA3' & VEGF120 & 330 \\
\hline rVEGF2 & & VEGF188 & 444 \\
\hline S & 5'GACCCTGGTGGACATCTTCCAGGA3' & VEGF164 & 372 \\
\hline AS & 5'GTTTAACTCAAGCTGCCTCGC3' & & \\
\hline$\beta_{2}$-Microglobulin & & & 188 \\
\hline S & 5'CAGATCTGTCCTTCAGCAAG3' & & \\
\hline AS & 5'GGAGTAAACTGGTCCAGATG3' & & \\
\hline
\end{tabular}

r, Rat; S, sense; AS, antisense.

glucose. The purpose of this study was to investigate the expression of VEGF mRNA isoforms and protein in cultured rat mesangial cells in response to high glucose and to identify whether increased production of VEGF is dependent on the protein kinase $\mathrm{C}$ (PKC) pathway.

\section{Materials and Methods}

\section{Rat mesangial cell culture}

Kidneys were removed from $100 \mathrm{~g}$ non-diabetic SpragueDawley rats, decapsulated and the cortex dissected. The isolated cortical tissue was minced into $0.5-1 \mathrm{~mm}$ fragments and pressed through nylon sieves of decreasing pore size $(225,150$ and $75 \mu \mathrm{m})$. The glomeruli were collected from the $75 \mu \mathrm{m}$ screen, centrifuged and suspended in PBS containing $0 \cdot 1 \%$ collagenase. After $20-30 \mathrm{~min}$ incubation at $37^{\circ} \mathrm{C}$, digested glomerular cores were suspended in Dulbeco's Modified Eagle's Medium (DMEM) (Sigma, St Louis, MO, USA) buffered with $10 \mathrm{mM}$ HEPES at $\mathrm{pH} 7 \cdot 4$ and supplemented with $17 \%$ fetal bovine serum (FBS), 2 mM L-glutamine, $100 \mathrm{~g} / \mathrm{ml}$ penicillin, $100 \mathrm{~g} / \mathrm{ml}$ streptomycin and $5 \mathrm{~g} / \mathrm{ml}$ insulin. Primary cultures were grown at $37^{\circ} \mathrm{C}$ and $5 \% \mathrm{CO}_{2}$; media were changed every $48 \mathrm{~h}$ for $8-10$ days, at which time mesangial cells reached confluence, outgrowing epithelial cells, and then were subcultured. The purity of mesangial cell lines was assessed by morphology under phase-contrast microscopy and by immunohistochemistry. Mesangial cells were not stained for factor VIII and non-specific esterases. Glomerular mesangial cells were grown as monolayers on $30 \mathrm{~mm}$ culture dishes. Once confluent, the cells were passaged after incubation with $0.5 \mathrm{ml} 0.25 \%$ trypsin and $0.01 \%$ EDTA for $5 \mathrm{~min}$ at $37^{\circ} \mathrm{C}$. Mesangial cells obtained at the 4th to 6th passages were used in this study.

\section{Experimental design}

The subconfluent cell monolayers were cultured in serumdeprived media containing $5 \mathrm{mM}$ D-glucose and 1\% FBS for $48 \mathrm{~h}$ and then divided into three experimental groups according to glucose concentration. The normal glucose (NG) group comprised confluent cell monolayers cultured with $5 \mathrm{mM}$ D-glucose, the medium glucose (MG) group was cultured in $15 \mathrm{mM}$ D-glucose and the high glucose (HG) group was cultured in $30 \mathrm{mM}$ D-glucose. Confluent cells were taken at $0,3,6$ and $24 \mathrm{~h}$ after growth in the different glucose concentrations and used for the extraction of total RNA and protein. Alternatively, calphostin-C as a PKC inhibitor and phorbol myristate acetate (PMA) as a PKC downregulator were instilled into the culture media to observe the role of $\mathrm{PKC}$ in mediating the glucose-induced increase in VEGF expression. The effect of the PKC inhibitor was observed in cultured mesangial cells coincubated with $200 \mathrm{nM}$ calphostin-C in highglucose media containing $30 \mathrm{mM}$ D-glucose. Total RNA and protein were extracted at $0,3,6$ and $24 \mathrm{~h}$. To determine the effect of PKC down-regulation, cultured rat mesangial cells were treated with $10^{-7} \mathrm{M}$ PMA for $24 \mathrm{~h}$ and then incubated with $30 \mathrm{mM}$ D-glucose for $3 \mathrm{~h}$, and finally total RNA and protein were extracted.

As the osmotic control group for the HG group, cultured mesangial cell monolayers were exposured to mannitol osmotic control medium containing $5 \mathrm{mM}$ D-glucose and $25 \mathrm{mM}$ mannitol for $3 \mathrm{~h}$ and then total RNA and protein were extracted.

Expression of VEGF $m R N A$ using semi-quantitative reverse transcription-polymerase chain reaction (RT-PCR)

Two sets of primers to amplify at least three splicing variants of rat VEGF mRNA - VEGF188, VEGF164 and VEGF120 - were used (Table 1, Fig. 1). The first set of rat VEGF (rVEGF1) primers included introns between amplification sites from exon 3 to $3^{\prime}$ untranslated ends and amplified three splicing variants of VEGF (VEGF188, VEGF164 and VEGF120; expected lengths of their PCR products were $514 \mathrm{bp}, 462 \mathrm{bp}$ and $330 \mathrm{bp}$ respectively). The second set of rVEGF primers (rVEGF2) included 


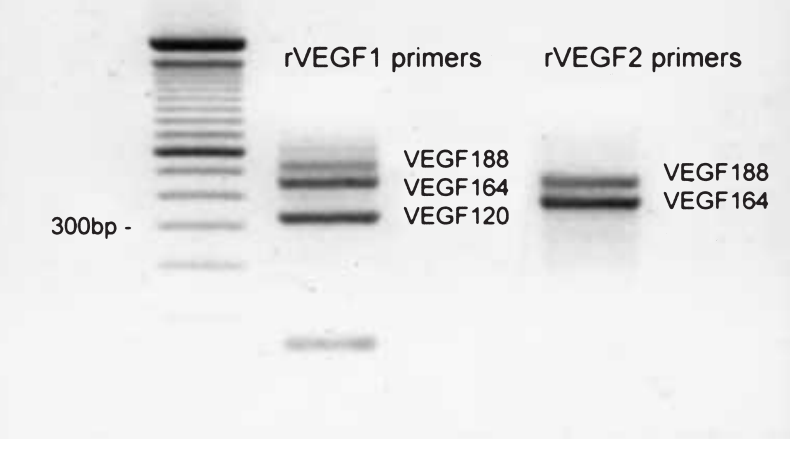

Figure 1 VEGF analysis from rat mesangial cells cultured on 2\% agarose gels followed by RT-PCR. Three VEGF isoforms - including VEGF188, VEGF164 and VEGF120 - were amplified by rat VEGF1 (rVEGF1) primers, and two splicing variants of VEGF transcripts encoding polypeptides of VEGF188 and VEGF164 were amplified by rVEGF2 primers. The sizes of the PCR products were compared against a 100 bp DNA ladder.

introns between amplification sites from exon 3 to exon 7 and amplified two splicing variants of VEGF188 and VEGF164 (expected lengths of their PCR products: $444 \mathrm{bp}$ and $372 \mathrm{bp}$ respectively). $\beta_{2}$-microglobulin was also amplified as an internal control for transcription and amplification; the expected length of its PCR product was 188 bp.

Total RNA was isolated from cultured mesangial cells using TriZol LS Reagent (Life Technologies, Gaithersberg, MD, USA) and then $1 \mu \mathrm{g}$ total RNA was reverse transcribed into cDNA using Moloney murine leukemia virus reverse transcriptase with oligo-(dT)12-18 primers (Life Technologies). Only $1 \cdot 25 \%$ of the resulting cDNA was amplified. The PCR cycle consisted of: $94{ }^{\circ} \mathrm{C}$ for $30 \mathrm{~s}, 58^{\circ} \mathrm{C}$ for $30 \mathrm{~s}$ and $72{ }^{\circ} \mathrm{C}$ for $90 \mathrm{~s}$; this was repeated for 35 cycles (VEGF) or 30 cycles ( $\beta_{2}$-microglobulin). The number of PCR cycles selected represented a point before the plateau of amplification products (Jung et al. 1999). A reaction product of the predicted length was separated on a $2 \%$ agarose gel with ethidium bromide staining and scanned at 300 d.p.i. and then densitometric analysis was performed for quantification using NIH image analysis software (version 1.61) with available gel macro and linear regression analysis. Some PCR products were ligated into the pGEM-T Easy vector (Promega, Madison, WI, USA) and sequenced using an ABI automated DNA sequencing system. Plasmid DNAs containing VEGF or $\beta_{2}$-microglobulin cDNA were amplified for positive controls. Control PCR reactions containing taq polymerase and the primer combination, but no template, were used for negative controls in PCR.

Presumptive concentrations of VEGF mRNA and $\beta_{2^{-}}$ microglobulin mRNA were evaluated on titration curves (Jung et al. 1999). Finally, the ratios of the concentration of $\beta_{2}$-microglobulin to those of the three VEGF isoforms (VEGF188, VEGF164, VEGF120) and the relative abundance of splicing variants of VEGF, such as the ratio of VEGF120 to VEGF164, were evaluated.

\section{Expression of VEGF protein using western blotting}

After exposure to different culture media, cultured mesangial cells were taken after washing with $2 \mathrm{ml}$ physiologic salt solution and the addition of lysis buffer, then centrifuged for $15 \mathrm{~min}$ at 12000 r.p.m. Protein was collected from the supernatant fraction and $50 \mu \mathrm{g}$ electrophoresed on a $12 \%$ SDS-polyacrylamide gel. Proteins in the gel were then transferred to a nitrocellulose membrane and the blot incubated on a shaker in $0 \cdot 1 \mathrm{ng} / \mu \mathrm{l}$ anti-VEGF monoclonal antibody (Santa Cruz Biotechnology Inc., Santa Cruz, CA, USA) at room temperature. Its detection was carried out by enhanced chemiluminescence (ECL) using ECL western blotting detection reagents according to the manufacturer's recommendation (Amersham, Bucks, UK).

\section{Statistics}

Results were expressed as mean \pm s.D. A significance level of $5 \%$ was chosen for all the tests $(P=0 \cdot 05)$. Statistical analysis was by Student's $t$-test using an SPSS-win PC computer program.

\section{Results}

\section{VEGF $m R N A$ expression under various glucose concentrations}

RT-PCR of rat mesangial cells using rVEGF1 primers revealed three alternative splicing variants: 330,462 and $514 \mathrm{bp}$ DNA fragments, corresponding to VEGF120, VEGF164 and VEGF188 (Fig. 1). Two alternative splicing variants that comprised 377 and $439 \mathrm{bp}$ DNA fragments corresponding to VEGF164 and VEGF188 were also amplified by rVEGF2 primers (Fig. 1).

Expression of VEGF and $\beta_{2}$-microglobulin mRNA under various glucose concentrations was observed on RT-PCR. Very low levels of VEGF isoforms were expressed in the NG group cultured with $5 \mathrm{mM}$ D-glucose. However, the MG group cultured with $15 \mathrm{mM}$ D-glucose revealed moderate VEGF expression and the HG group cultured with $30 \mathrm{mM}$ D-glucose revealed high levels of VEGF isoforms, with peak expression at $3 \mathrm{~h}$ (Fig. 2). Expression of $\beta_{2}$-microglobulin was identified at nearly constant levels.

Mesangial cells in the NG group expressed very low levels of VEGF and the ratio of $\beta_{2}$-microglobulin to VEGF164 was $0.03 \pm 0.03$. In the $M G$ group this ratio was increased to $0.12 \pm 0.07$ at $3 \mathrm{~h}, 0.05 \pm 0.02$ at $6 \mathrm{~h}$ and $0.03 \pm 0.01$ at $24 \mathrm{~h}$. The ratio in the HG group was also 
VEGF (1)

- $0 \mathrm{~h} 3 \mathrm{~h} 6 \mathrm{~h} 24 \mathrm{~h}$
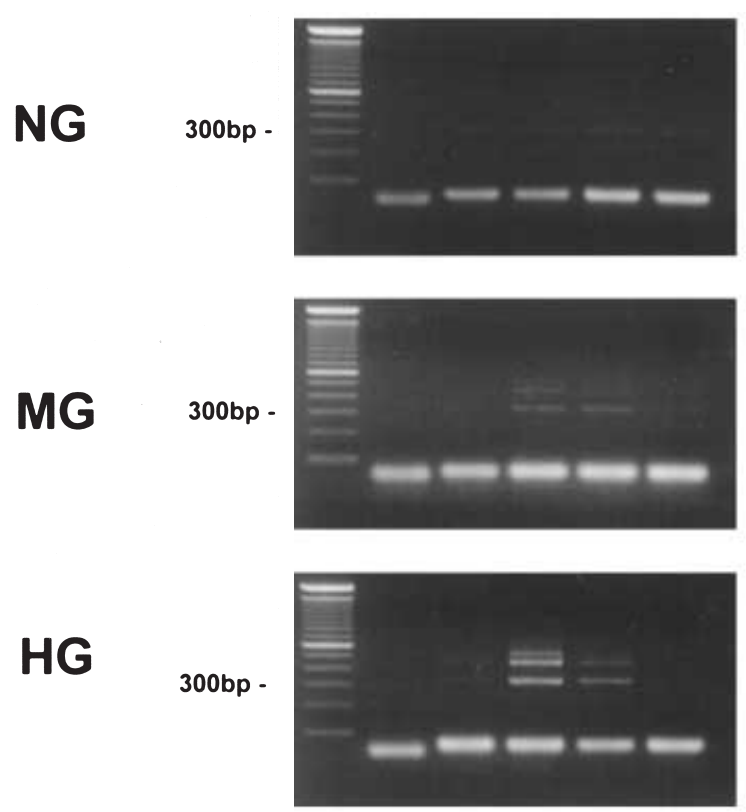

VEGF (2) - Oh $3 h$ 6h $24 h$
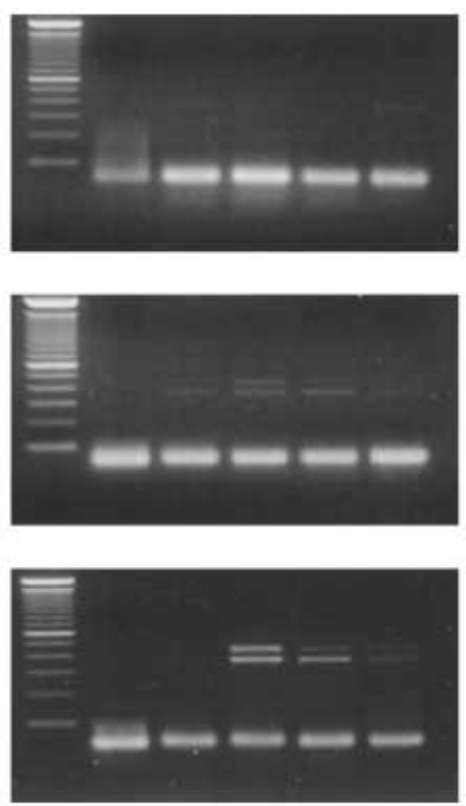

$\beta_{2}-$ microglobulin

- Oh $3 h$ 6h $24 h$
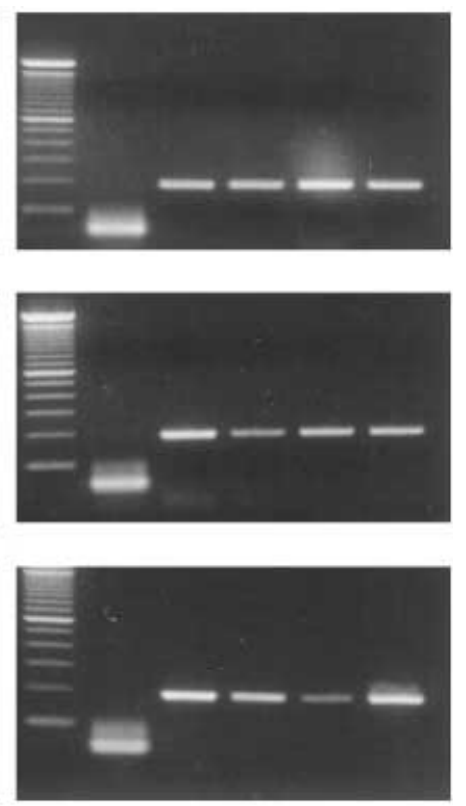

Figure 2 Expression of VEGF and $\beta_{2}$-microglobulin mRNA under various glucose concentrations. Very low levels of VEGF isoforms were expressed in the NG group cultured with $5 \mathrm{mM}$ D-glucose, the MG group cultured with $15 \mathrm{mM}$ D-glucose revealed weak expression of VEGF and the HG group cultured with $30 \mathrm{mM}$ D-glucose revealed high levels of VEGF isoforms with peak expression at $3 \mathrm{~h}$. Expression of $\beta_{2}$-microglobulin was identified at nearly constant levels. VEGF (1) and VEGF (2), VEGF mRNA expression using rVEGF1 and rVEGF2 primers; -, negative control.

markedly increased, to $0 \cdot 48 \pm 0 \cdot 1$ at $3 \mathrm{~h}, 0 \cdot 25 \pm 0 \cdot 08$ at $6 \mathrm{~h}$ and $0 \cdot 04 \pm 0 \cdot 05$ at $24 \mathrm{~h}(P=0 \cdot 016, P=0 \cdot 044, P>0 \cdot 05)$ (Fig. 3). The HG group at $3 \mathrm{~h}$ expressed fourfold more VEGF164 than the MG group at $3 \mathrm{~h}$.

The ratio of $\beta_{2}$-microglobulin to VEGF120 was similar to that of VEGF164. It was increased to $0 \cdot 17 \pm 0 \cdot 15$ at $3 \mathrm{~h}$ and $0.09 \pm 0.03$ at $6 \mathrm{~h}$ in the $\mathrm{MG}$ group $(P=0.03$, $P=0.043)$, but was markedly increased to $0.57 \pm 0 \cdot 10$ at $3 \mathrm{~h}$ and $0.48 \pm 0.08$ in the $\mathrm{HG}$ group $(P=0.012$, $P=0.014$ ) (Fig. 4). At $3 \mathrm{~h}$ the $\mathrm{HG}$ group also expressed threefold more VEGF120 than did the MG group.

The ratio VEGF120/VEGF164 was $1.36 \pm 0.64$ in the HG group at $3 \mathrm{~h}$, suggesting that VEGF120 was expressed more than VEGF164.

The nucleotide sequences of some of the above PCR products cloned to plasmid vectors were identical to previously published details (Gene accession numbers: AF0624 for VEGF188, M32167 for VEGF164, L20913 for VEGF120 and Y08532 for $\beta_{2}$-microglobulin).

Effects of PKC inhibitor and PKC downregulator on VEGF $m R N A$ expression

When mesangial cells were cultured with $200 \mathrm{nM}$ calphostin-C in high glucose media containing $30 \mathrm{mM}$
D-glucose, VEGF164/ $\beta_{2}$-microglobulin ratios at $3 \mathrm{~h}$ and $6 \mathrm{~h}$ were markedly decreased in comparison with those in the HG group, to $0 \cdot 09 \pm 0.06$ and $0.03 \pm 0.03(P=0.04$, $P=0 \cdot 071)$. VEGF120/ $\beta_{2}$-microglobulin ratios at $3 \mathrm{~h}$ and $6 \mathrm{~h}$ were also decreased, to $0 \cdot 13 \pm 0.07$ and $0.05 \pm 0.03$ $(P=0.003, P=0.014)$ compared with the HG group (Figs 3-5). Similarly, mesangial cells, when pretreated with $10^{-7} \mathrm{M}$ PMA for $24 \mathrm{~h}$ and incubated with $30 \mathrm{mM}$ D-glucose for $3 \mathrm{~h}$, revealed less expression of VEGF164 and VEGF120 transcripts at $3 \mathrm{~h}$ than did the HG group $(0.08 \pm 0.05$ and $0.06 \pm 0.05 ; P=0.034, P=0.035$ compared with the HG group). Mesangial cells exposed to $25 \mathrm{mM}$ mannitol for $3 \mathrm{~h}$ revealed no differences in the expression of VEGF transcripts compared with the NG group.

\section{Expression of VEGF protein}

In western blotting (Fig. 6), the NG group expressed very low levels of VEGF protein. However, distinct bands on the autoradiograph were observed at approximately $42 \mathrm{kDa}$ in the $\mathrm{MG}$ and $\mathrm{HG}$ groups from 3 to $24 \mathrm{~h}$ : the $\mathrm{MG}$ group at $3 \mathrm{~h}$ revealed moderate levels of VEGF protein expression, whereas the $\mathrm{HG}$ group at $3 \mathrm{~h}$ revealed 


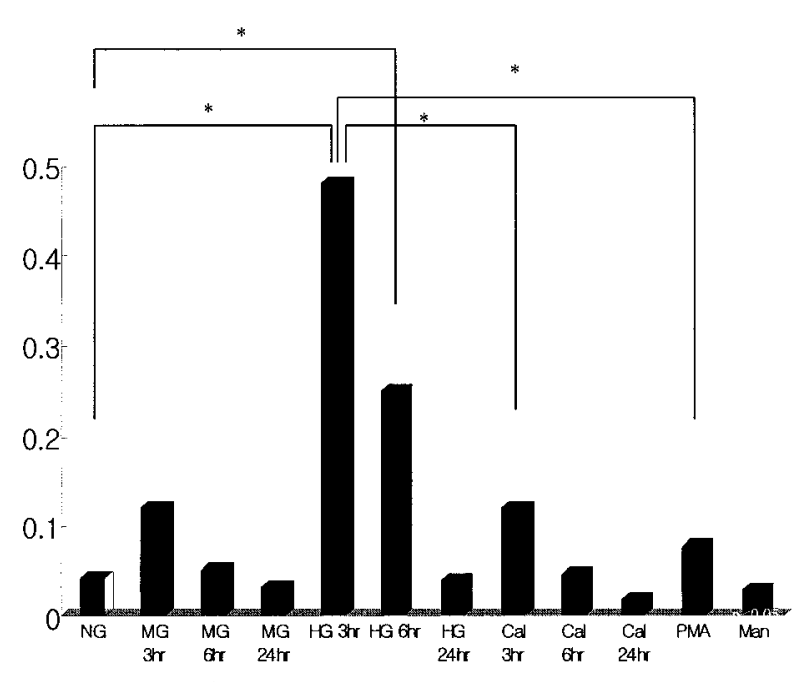

Figure 3 Ratio of VEGF164 to $\beta_{2}$-microglobulin in each experimental condition. Peak expression of VEGF164/ $\beta_{2^{-}}$ microglobulin was observed at $3 \mathrm{~h}$ in the HG group. ${ }^{*}$ Significant differences $(P<0 \cdot 05$, Student's $t$-test using an SPSS-win PC computer program). Cal, calphostin-C; Man, mannitol $3 \mathrm{~h}$.

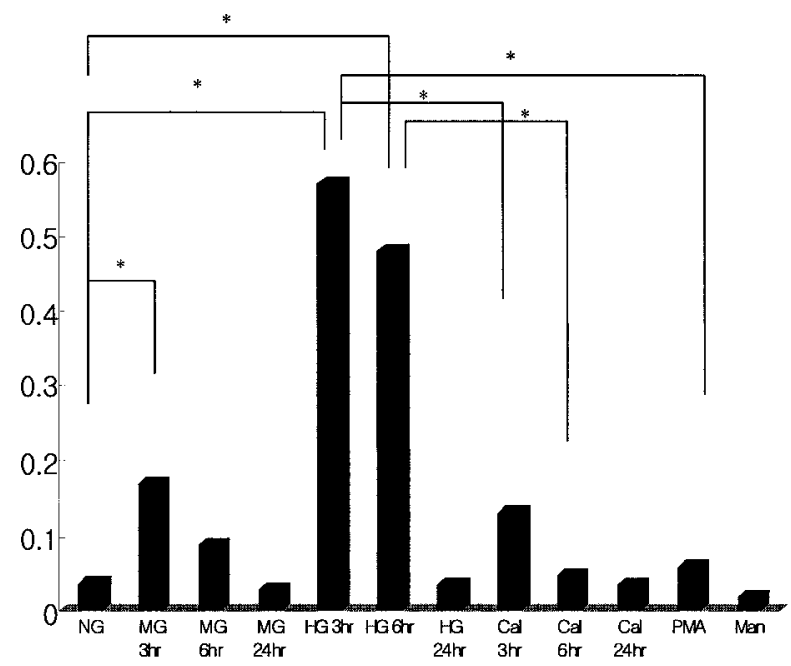

Figure 4 Ratio of VEGF120 to $\beta_{2}$-microglobulin in each experimental condition. Peak expression of VEGF120/ $\beta_{2^{-}}$ microglobulin was observed at $3 \mathrm{~h}$ in the $\mathrm{HG}$ group. * ${ }^{*}$ tatistically significant differences $(P<0 \cdot 05)$. Cal, calphostin-C; Man, mannitol $3 \mathrm{~h}$.

very high levels of VEGF protein expression. The calphostin-C-treated group cultured in high-glucose conditions expressed low levels of VEGF protein and the PMA-treated group in high glucose revealed very low levels of VEGF expression. The mannitol-treated group at $3 \mathrm{~h}$ had no effect on VEGF expression.

\section{Discussion}

The present study clearly demonstrates that high concentrations of glucose in rat cultured mesangial cells upregulated VEGF expression at the mRNA and protein levels in a time-dependent manner. This finding is very similar to a previous report that increased glucose concentrations markedly increase VEGF mRNA expression in human vascular smooth muscle cells and that hyperglycemia could contribute directly to the development of endothelial dysfunction and neovascularization in diabetes mellitus (Williams et al. 1997). The present findings suggest that glomerular mesangial cells in high-glucose conditions express VEGF and that this could be a primary source of the increased vascular permeability and endothelial dysfunction in diabetic nephropathy.

Although the role for VEGF in the regulation of glomerular permeability is unclear, VEGF could be a potential mediator of glomerular hyperfiltration and proteinuria in the development of diabetic nephropathy. The mechanism underlying proteinuria could be explained by a recent report that VEGF stimulates the increased production of collagenase by endothelial cells and its angiogenic properties may play a part in the pathogenesis of protein extravasation through the proteolytic disruption of endothelial basement membrane (Unemori et al. 1992). Therefore, extravasation of plasma protein in diabetic nephropathy may be related to the physiologic role of VEGF that seems to be key to the regulation of glomerular permeability to protein. Alternatively, VEGF is known to be involved in the production of nitric oxide and of prostacyclin (Zachary 1998), which have been implicated in the pathogenesis of glomerular hyperfiltration (Craven et al. 1997).

Del Prete et al. (1998) proposed a pathogenetic scheme whereby VEGF could be a mediator of glomerulosclerosis. Glomerular permeabilization by VEGF might induce both albuminuria and an increased mesangial traffic of growth factors from the circulating blood. Growth factors might also originate from activated endothelial cells as a result of the mitogenic activity of VEGF. Growth factors might then induce matrix synthesis by mesangial cells, leading to glomerulosclerosis. In the present study, VEGF expression was maximal at $3 \mathrm{~h}$ in the $\mathrm{HG}$ group and then decreased. This finding is similar to those of the study of human vascular smooth muscle cells, in which high glucose concentrations increased VEGF mRNA expression within $3 \mathrm{~h}$ (Williams et al. 1997). Immediate release of VEGF in response to hyperglycemia, but not continuous release, could not be responsible for glomerulosclerosis. However, hyperglycemia for a long period in vivo may stimulate VEGF expression for a more prolonged period because hyperglycemia with co-stimuated cytokines appears to act synergistically to enhance VEGF expression.

VEGF mRNA splicing occurs in a tissue-specific manner and the relative abundance of the various forms expressed differs among tissues (Bacic et al. 1995). VEGF206 and VEGF189/188 are known to be primarily cell associated, whereas VEGF165/164 and VEGF121/120 are secretory forms. It is still unclear which isoform 


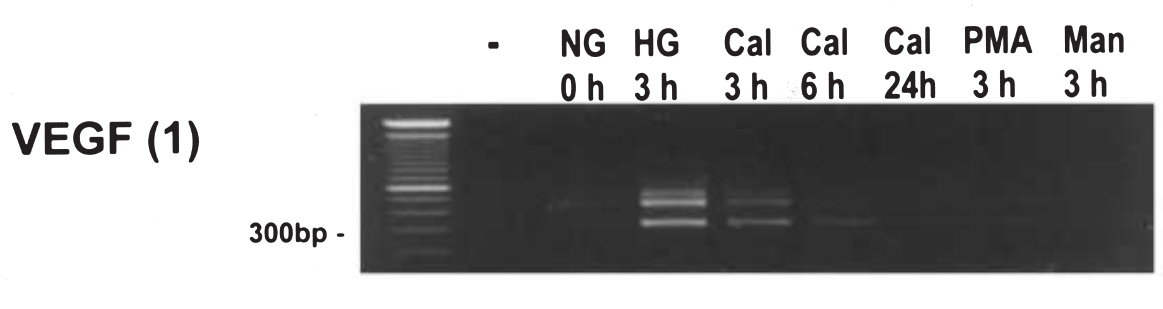

VEGF (2)

$300 \mathrm{bp}$ -

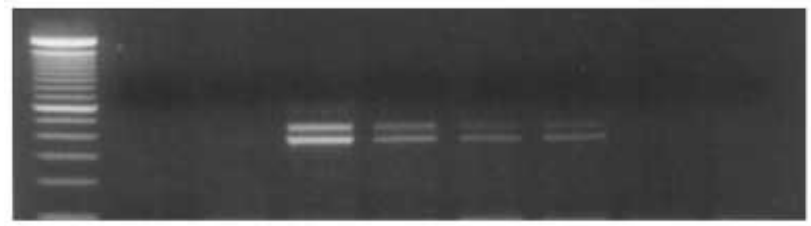

\section{$\beta_{2}$-microglobulin}

$300 \mathrm{bp}$ -

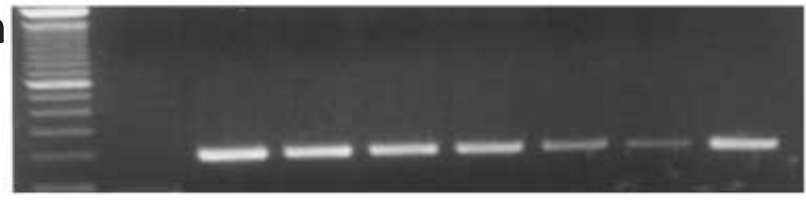

Figure 5 Effects of the PKC inhibitor calphostin-C (Cal) and the PKC downregulator PMA on VEGF mRNA expression after various periods of cell culture. VEGF mRNA expression was significantly reduced in calphostin-C- and PMA-treated groups, whereas mannitol (Man) had no effect on VEGF mRNA expression. -, Negative control; VEGF (1) and VEGF (2), VEGF mRNA expression using rVEGF1 and rVEGF2 primers.

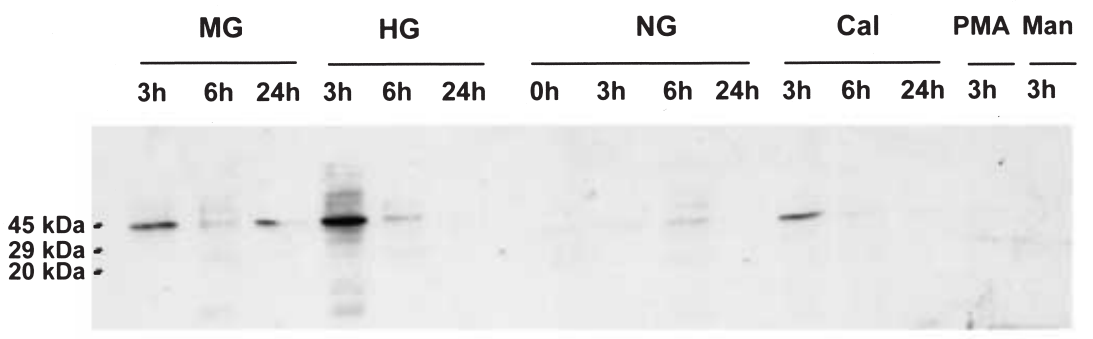

Figure 6 Western blotting for VEGF. Distinct bands of VEGF dimers on the autoradiograph were observed at approximately $42 \mathrm{kDa}$ in various conditions. The NG group expressed very low levels of VEGF protein, but the MG group at $3 \mathrm{~h}$ revealed moderate levels of expression and the $\mathrm{HG}$ group at $3 \mathrm{~h}$ revealed very high levels of expression. The calphostin-C (Cal)treated group cultured in high-glucose conditions expressed low levels of VEGF protein and the PMA-treated group in high glucose revealed very low levels of VEGF expression. The mannitol (Man)-treated group at $3 \mathrm{~h}$ had no effect on VEGF expression.

predominates in normal or pathologic conditions. VEGF164 is the most abundant product of the VEGF gene except in the placenta, where VEGF121 is most abundant (Ferrara et al. 1992). In the present study, glucose-induced expression of VEGF120 was slightly greater than that of VEGF164 in rat mesangial cells. Conversely, normal human respiratory and digestive epithelial tissues express more VEGF165 than VEGF121, but the reverse occurs in the inflammatory reactions (unpublished observation). This finding implies that different secretory patterns can occur in high-glucose conditions, providing a possible different physiologic role of each VEGF isoform.

Secretory forms of VEGF bind to two high-affinity receptors, kinase insert domain-containing receptor 
(KDR) and fms-like tyrosine kinase-1 (flt-1), predominantly located on vascular endothelium, and stimulate vascular permeability and endothelial cell growth (Connolly et al. 1989, Houck et al. 1991, Terman et al. 1992, de Vries et al. 1992). It is unknown whether a specific receptor subtype preferentially transduces specific VEGF functions (i.e. permeability or angiogenesis). Even though the mechanisms underlying the signal pathway via the VEGF receptors have yet to be completely defined, the VEGF-mediated increase in microvascular permeability appears to be calcium dependent. In the present study, PKC inhibition and downregulation prevented a glucose-induced increase in VEGF production, suggesting that upregulation of VEGF expression in response to high glucose is mediated via a PKC-dependent pathway. This was also demonstrated in smooth muscle cells in response to high glucose (Williams et al. 1997). Therefore, it could be possible that the PKC inhibitor is capable of suppressing the VEGF-induced early albuminuria in a rat diabetic model.

Hypoxia-induced VEGF expression in retinal microvascular cells has been reported to be dependent on the release of adenosine and adenosine-induced activation of cAMP-dependent protein kinase A via the A2a receptor (Takagi et al. 1996). It is also possible that calcium ionophores, cAMP analogs and phorbol esters activate VEGF expression, indicating the involvement of intracellular calcium, PKC and cAMP-dependent kinases in the regulation of VEGF expression (Claffey et al. 1992).

Clinically, VEGF could potentially play a role in the pathophysiology of glomerular hyperfiltration, proteinuria and glomerulosclerosis in diabetic patients. An improved understanding of the cellular regulation of VEGF production and VEGF receptor expression and function may ultimately yield novel and potent adjunctive treatments to limit the microvascular complications of diabetes mellitus, especially diabetic nephropathy.

\section{Acknowledgements}

We thank Dr Jae Hyuck Lee and June Hee Kim for their technical assistance and Dr Sei Hyun Baik and Dr Sang Jin Kim for helpful discussion.

\section{References}

Bacic M, Edwards NA \& Merrill MJ 1995 Differential expression of vascular endothelial growth factor (vascular permeability factor) forms in rat tissues. Growth Factors 12 11-15.

Brown LF, Berse B, Tognazzi K, Manseau EJ, Van DeWater L, Senger DR, Dvorak HF \& Rosen S 1992 Vascular permeability factor mRNA and protein expression in human kidney. Kidney International 42 1457-1461.

Claffey K, Wilkison WO \& Spiegelman BM 1992 Vascular endothelial growth factor: regulation by cell differentiation and activated second messenger pathway. Journal of Biological Chemistry 267 16317-16322.
Conn G, Bayne ML, Soderman DD, Kwok PW, Sullivan KA, Palisi TM, Hope DA \& Thomas KA 1990 Amino acid and cDNA sequences of a vascular endothelial cell mitogen that is homologous to platelet-derived growth factor. PNAS 87 2628-2632.

Connolly DT, Heuvelman DM, Nelson R, Olander JV, Eppley BL, Delfino JJ, Seigel NR, Leimgruber RM \& Feder J 1989 Tumor vascular permeability factor stimulates endothelial cell growth and angiogenesis. Journal of Clinical Investigation 84 1470-1478.

Craven PA, DeRubertis FR \& Melhem M 1997 Nitric oxide in diabetic nephropathy. Kidney International 52 (Suppl 60) S46-S53.

Del Prete D, Anglani F, Ceol M, D'Angelo A, Forino M, Vianello D, Baggio B \& Gambaro G 1998 Molecular biology of diabetic glomerulosclerosis. Nephrology, Dialysis, Transplantation 13 (Suppl 8) $20-25$.

Ferrara N, Houck K, Jakeman L \& Leung DW 1992 Molecular and biological properties of the vascular endothelial growth factor family of proteins. Endocrine Reviews 13 18-31.

Houck KA, Ferrara N, Winer J, Cachianes G, Li B \& Leung DW 1991 The vascular endothelial growth factor family: identification of a fourth molecular species and characterization of alternative splicing of RNA. Molecular Endocrinology 5 1806-1814.

Iijima K, Yoshikawa N, Connolly DT \& Nakamura H 1993 Human mesangial cells and peripheral blood mononuclear cells produce vascular permeability factor. Kidney International 44 959-966.

Jung HH, Kim MW, Lee JH, Kim YT, Kim NH, Chang BA, Choi JO \& Lim HO 1999 Expression of vascular endothelial growth factor in otitis media. Acta Otolaryngologica 119 801-808.

Ladoux A \& Frelin C 1993 Expression of vascular endothelial growth factor by cultured endothelial cells from brain microvessels. Biochemical and Biophysical Research Communications 194 799-803.

Leung DW, Cachianes G, Kaung WJ, Goeddel WV \& Ferrara N 1989 Vascular endothelial growth factor is a secreted angiogenic mitogen. Science 246 1306-1309.

Pettitt DJ, Saad MF, Bennett PH, Nelson RG \& Knowler WC 1990 Familiar predisposition to renal disease in two generation of Pima Indians with type 2 (non-insulin-dependent) diabetes mellitus. Diabetologia 33 438-443.

Pugh JA, Medina R \& Ramirez M 1993 Comparison of the course to end-stage renal disease of type 1 (insulin-dependent) and type (noninsulin-dependent) diabetic nephropathy. Diabetologia 36 1094-1098.

Senger DR, Connolly DT, Van de Water L, Feder J \& Dvorak HF 1990 Purification and NH2-terminal amino acid sequence of guinea pig tumor-secreted vascular permeability factor. Cancer Research 50 1774-1778.

Senger DR, Van Der Water L, Brown LF, Nagy JA, Yeo KT, Yeo TK, Berse B, Jackson RW \& Dvorak AM 1993 Vascular permeability factor in tumor biology. Cancer and Metastasis Reviews 12 303-324.

Sharma K \& Ziyadeh FN 1997 Biochemical events and cytokine interactions linking glucose metabolism to the development of diabetic nephropathy. Seminars in Nephrology 17 80-92.

Takagi H, King GL, Robinson GS, Ferrara N \& Aiello LP 1996 Adenosine mediates hypoxic induction of vascular endothelial growth factor in retinal microvascular endothelial cells. Investigative Ophthalmology Visual Science 37 2165-2176.

Terman BI, Dougher-Vermazen M, Carrion ME, Dimitrov D, Armellino DC, Gospodarowicz D \& Bohlen P 1992 Identification of the KDR tyrosine kinase as a receptor for vascular endothelial cell growth factor. Biochemical and Biophysical Research Communications 187 1579-1586.

Unemori EN, Ferrara N, Bauer EA \& Amento EP 1992 Vascular endothelial growth factor induces interstitial collagenase expression in human endothelial cells. Journal of Cell Physiology 153 557-562.

de Vries C, Escobedo JA, Ueno H, Houck K, Ferrara N \& Williams LT 1992 The fms-like tyrosine kinase, a receptor for vascular endothelial growth factor. Science 255 989-991. 
Williams B, Gallacher B, Patel H \& Orme C 1997 Glucose-induced protein kinase $\mathrm{C}$ activation regulates vascular permeability factor mRNA expression and peptide production by human vascular smooth muscle cells in vitro. Diabetes 46 1497-1503.

Wolf G \& Ziyadeh FN 1997 The role of angiotensin II in diabetic nephropathy: emphasis on nonhemodynamic mechanisms. American Journal of Kidney Disease 29 153-163.
Zachary I 1998 Vascualar endothelial growth factor: how it transmits its signal. Experimental Nephrology 6 480-487.

Received 17 August 1999

Accepted 27 January 2000 